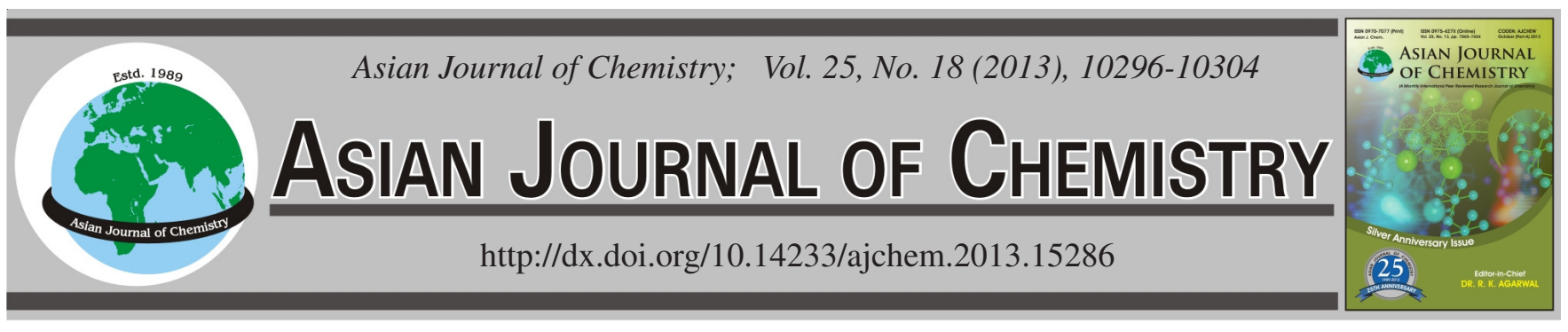

\title{
Characterization of Protostane Triterpenoids in Dried Tuber of Alisma orientalis by Q-TOF Mass Spectrometry in Both Positive and Negative Modes
}

\author{
Chengwu Song ${ }^{1, \dagger}$, Long Huang ${ }^{2,3, \dagger}$, Xiaofei Huang ${ }^{1}$, Rongzeng Huang ${ }^{1}$, Min Peng ${ }^{4}$, \\ ZhiYong LE ${ }^{5}$, Ye Song ${ }^{1}$, ShangGong YU ${ }^{1, *}$ and Nianbai Fang ${ }^{1}$
}

\begin{abstract}
${ }^{1}$ Key Laboratory of Chinese Medicine Resource and Compound Prescription (Hubei University of Chinese Medicine), Ministry of Education, 1 Huang-jia-hu, Wuhan 430065, P.R. China

${ }^{2}$ Technology Center of China Tobacco Hubei Industry Corporation, Wuhan 430040, P.R. China

${ }^{3}$ Wuhan Huanghelou Flavors \& Fragrances Co. Ltd., Wuhan 430040, P.R. China

${ }^{4}$ Wuhan Hospital of Traditional Chinese Medicine, 49 Lihuangpi Road, Jiangan District, Wuhan 430014, P.R. China

${ }^{5}$ Industrial Park Huaian District, Zhenhai Road, Jiangsu 223200, P.R. China
\end{abstract}

*Corresponding author: Tel/Fax: +86 27 68890247; E-mail: yu20110425@hotmail.com

$\dagger$ These authors contributed equally to this work.

Key Words: Alisma orientale, Ze Xie, Protostane triterpenoids, Q-TOF-MS.

\section{INTRODUCTION}

Alisma orientalis belongs to Alismataceae and its dried tuber is known in traditional Chinese medicine (TCM) as Ze Xie. Ze Xie has been recorded in various editions of Pharmacopoeias in China. As a valuable therapeutic TCM, Ze Xie is prescribed in many classic TCM formulas for treatment of oliguresis and edema. The hypolipidemic effect of Ze Xie has been reported in our previous study ${ }^{1}$. The major components of $\mathrm{Ze} \mathrm{Xie} \mathrm{are} \mathrm{terpenes} \mathrm{including} \mathrm{protostane} \mathrm{triterpenoids,}$ kaurane diterpenes and guaiane sesquiterpenes ${ }^{2-7}$. Twenty protostane triterpenoids in Ze Xie have been characterized by Q-TOF-MS with positive mode ${ }^{8}$. In the present study, a chemical profile of Ze Xie was established by HPLC/Q-TOF-MS in both positive and negative modes. The structures of known components in Ze Xie were identified by comparing their retention times, high-resolution molecular weight and CID fragmentation patterns with their corresponding compounds reported in the literature. The unknown components were characterized by comparing the CID fragmentation behaviours in both positive and negative modes between the known and unknown components in Ze Xie.

\section{EXPERIMENTAL}

HPLC/MS grade acetonitrile was purchased from Fisher Scientific Company. Water was prepared using an Easy pure II UF ultrapure water system (Barnstead, USA). MS grade formic acid was purchased from Sigma-Aldrich (USA).

The plant of A. orientalis was grown in Sichuan Province, China. Dried tubers of A. orientalis (Ze Xie) were purchased from Xianning kang Jin Chinese Herbal Pieces Co., Ltd. (Hubei, China). The herb was identified and authenticated by the taxonomist of Key Laboratory of Chinese Medicine Resource and Compound Prescription (Hubei University of Chinese Medicine), Ministry of Education. A voucher specimen (No. 040) was deposited in herbarium of the Key Laboratory.

Sample preparation: Ze Xie was ground to a fine powder. Two $\mathrm{g}$ of Ze Xie powder was added with $10 \mathrm{~mL}$ of acetonitrile and vortexed vigorously for $2 \mathrm{~min}$ followed by sonication for $5 \mathrm{~min}$. The mixture was centrifuged and the supernate as an 
extract was removed carefully. The extraction process was repeated one time with the same solvent $(10 \mathrm{~mL})$. Two extracts were combined and directly analyzed by LC-MS/MS.

LC/MS analysis: The phytochemicals in an extract of Ze Xie were directly analyzed by LC-MS/MS. LC-MS/MS was performed using a MicrOTOF-Q II Focus mass spectrometer (Bruker Daltonics) equipped with an Agilent 1100 series liquid chromatograph. A $250 \mathrm{~mm} \times 4.6 \mathrm{~mm}$ i.d. Acclaim $\mathrm{C}_{18}$ column (Dionex, USA) was used at a flow rate of $0.5 \mathrm{~mL} \mathrm{~min}^{-1}$. The injection volume was $10 \mu \mathrm{L}$. The HPLC gradient was acetonitrile-formic acid (99.9: 0.1, v/v) (B) in water-formic acid (99.9: 0.1, v/v) (A). The following binary gradient with linear interpolation was used: $0 \mathrm{~min}, 35 \% \mathrm{~B}$; $20 \mathrm{~min}, 55 \% \mathrm{~B}$; $60 \mathrm{~min}, 65 \% \mathrm{~B}$; $75 \mathrm{~min}$, $100 \%$ B; 80 min, $35 \%$ B. HPLC chemical profiles of Ze Xie extract were determined by a diode-array detector (DAD) set at four wavelengths of 200, 245, 280 and $350 \mathrm{~nm}$. TIC chemical profiles of the extract were established in both positive and negative modes. HR-MS/MS analysis were carried out using a MicrOTOFQ II Focus mass spectrometer fitted with an ESI source operating in Auto-MS ${ }^{\mathrm{n}}$ mode to obtain fragment ion. Conditions for ESIMS analysis of HPLC peaks in both negative- and positive-ion mode included a capillary voltage of $3500 \mathrm{~V}$, an end plate offset of -500 V, a drying gas flow of $6 \mathrm{~mL} / \mathrm{min}$ and a dry heater temperature of $180{ }^{\circ} \mathrm{C}$ and a nebulizer pressure of 3.0 bar. The MS collision energy was set at $10 \mathrm{eV}$ and the MS/MS collision energy was set at 15 or $35 \mathrm{eV}$. The outflows were divided into three shares and only one share entered the MS detector.

\section{RESULTS AND DISCUSSION}

Chemical profile of Ze Xie extract in positive mode was essentially similar to that previously reported ${ }^{8}$. However, more phytochemicals were detected in the extract by Q-TOF-MS in the present study. Five major peaks 6, 20, 21, 24 and 28 (Fig. 1) have been identified as alisol C, alisol A, alisol A 23-acetate, alisol A 24-acetate and alisol B according to their molecular formula resulted from high-resolution MS and the same CID mass spectra with those reported in the literature ${ }^{8}$. Furthermore, compounds 3-5, 10-12, 14-18, 22, 23, 26 and 27 were newly found in Ze Xie extract. The structures of the compounds identified or characterized were shown in Fig. 2. Since chemical profiles of Ze Xie extract obtained in analyses of HPLC with DAD were not characteristic, the HPLC DAD-chromatograms were not shown here.

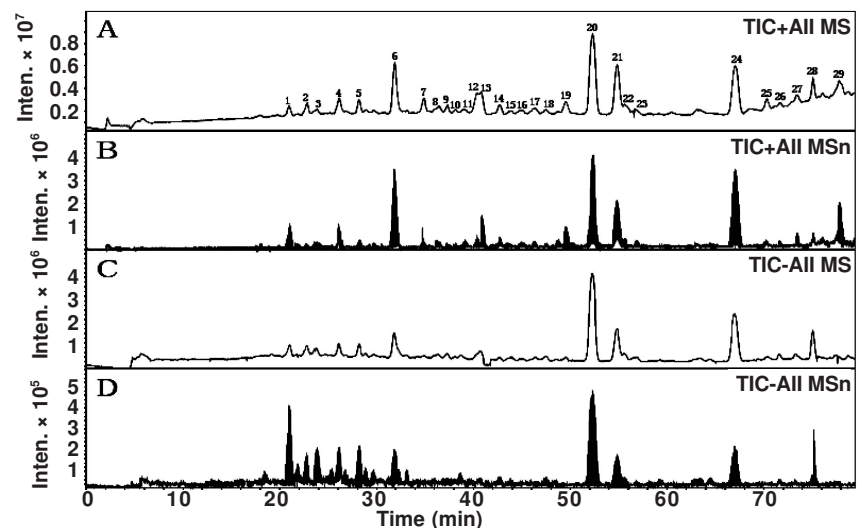

Fig. 1. TIC of acetonitrile extract of Ze Xie. A, TIC of positive All MS; B, TIC of positive All MS $;$; , TIC of negative All MS and $\mathbf{D}$, TIC of negative All MS ${ }^{\mathrm{n}}$

CID mass fragmentation behaviours of major protostane triterpenoids: HR-MS in positive mode of compound $\mathbf{6}$ exhibited an ion at $m / z 487.3110$ corresponding to $\mathrm{C}_{30} \mathrm{H}_{47} \mathrm{O}_{5}$

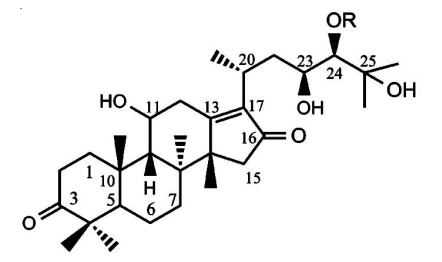

\begin{tabular}{ll} 
No. & $\mathrm{R}$ \\
\hline 1 & $\mathrm{H}$ \\
2 & Ac \\
3 & Olefination derivative of 1 \\
$4^{*}$ & Isomer of 2 \\
$5^{*}$ & Dihydro derivative of 1 \\
$10^{*}$ & Oxygen derivative of 2 \\
$17^{*}$ & Isomer of 1 \\
$18^{*}$ & Isomer of 10
\end{tabular}
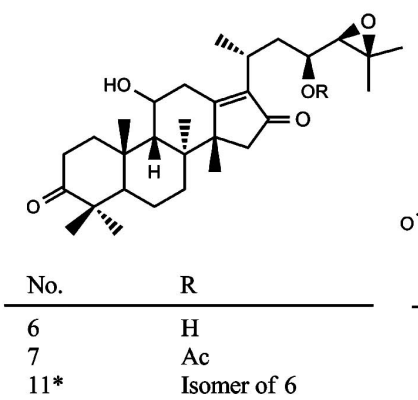

$12^{*}, 14^{*}, 15^{*} \quad$ Isomer of 7

$27^{*} \quad$ Olefination derivative

of 7
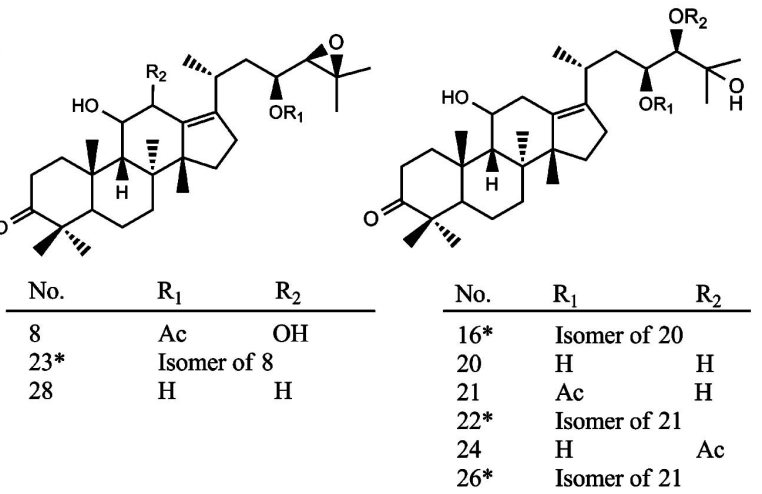

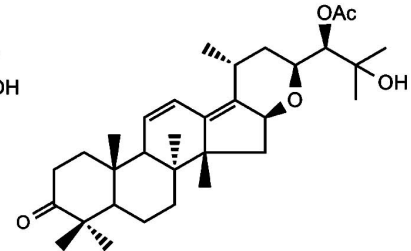

No. 19

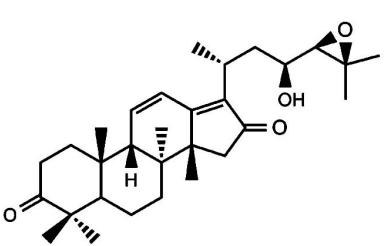

No. 29

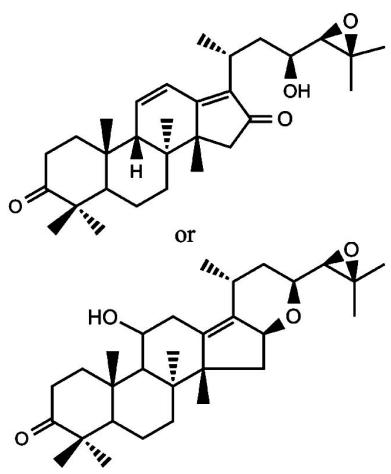

No. 25 was characterized as one of the sturctures above

Fig. 2. Structures of the compounds identified in Ze Xie. *: Since NMR data and the corresponding standards of these compounds were not available, identifications of these compounds could not be completed by the LC-MS/MS in this study 
$[\mathrm{M}+\mathrm{H}]^{+}$of alisol $\mathrm{C}$ (calculated for $\mathrm{C}_{30} \mathrm{H}_{47} \mathrm{O}_{5}, 487.3423$ ). The structure of compound $\mathbf{6}$ was identified as alisol $\mathrm{C}$ based on CID product ions. The product ions $\left[\mathrm{M}+\mathrm{H}-\mathrm{H}_{2} \mathrm{O}\right]^{+}$at $\mathrm{m} / \mathrm{z} 469$ and $\left[\mathrm{M}+\mathrm{H}-\mathrm{H}_{2} \mathrm{O}-\mathrm{H}_{2} \mathrm{O}\right]^{+}$at $\mathrm{m} / z, 451$ were generated by losing a series of $\mathrm{H}_{2} \mathrm{O}$ from a protonated molecular ion $[\mathrm{M}+\mathrm{H}]^{+}$at $\mathrm{m} / z$ 487. The product ion $\left[\mathrm{M}+\mathrm{H}-\mathrm{H}_{2} \mathrm{O}-\mathrm{C}_{4} \mathrm{H}_{8} \mathrm{O}\right]^{+}$at $\mathrm{m} / z 397$ was formed by cleavage of $\mathrm{C}_{23}-\mathrm{C}_{24}$ bond via hydrogen rearrangement at $\mathrm{C}_{23}-\mathrm{OH}$ from ion at $m / z 469$, as reported previously ${ }^{8}$. In addition, three product ions at $\mathrm{m} / \mathrm{z}$ values 381,367 and 353 were detected when MS/MS collision energy was set at $35 \mathrm{eV}$ (Fig. 3), which supported the structural elucidation. In negative mode, this compound exhibited an adduct of molecular ion $[\mathrm{M}+\mathrm{HCOOH}-\mathrm{H}]^{-}$at $\mathrm{m} / z, 531.3280$ corresponding to $\mathrm{C}_{31} \mathrm{H}_{47} \mathrm{O}_{7}$ (m.w. calculated for $\mathrm{C}_{31} \mathrm{H}_{47} \mathrm{O}_{7}, 531.3321$ ). The product ion [M-H-30] ${ }^{-}$at $m / z 455$ was formed by the neutral loss of $30 \mathrm{Da}\left(\mathrm{CH}_{2} \mathrm{O}\right)$ from parent ion at $\mathrm{m} / \mathrm{z} 485$ (Fig. 4) and this typical fragment was a common pathway for CID of triterpenoids ${ }^{9}$. The product ion at $m / z 367$ was formed by elimination of a $\mathrm{C}_{2} \mathrm{H}_{2} \mathrm{O}$ group and $\mathrm{H}_{2} \mathrm{O}$ from the ion at $\mathrm{m} / z 427$. The product ion at $m / z 399$ was generated due to the cleavage of a carbon bond at $\mathrm{C}_{24}$ position and a neutral loss of $16 \mathrm{Da}$ $\left(\mathrm{CH}_{4}\right)$ at $\mathrm{C}_{21}$ position to form a stable conjugated system. Interestingly, the product ion at $m / z 427$ from parent ion at $\mathrm{m} / \mathrm{z} 485$ was detected when MS/MS collision energy was set at a lower value of $15 \mathrm{eV}$, but not detected in the condition of high MS/MS collision energy $35 \mathrm{eV}$, which indicated the structure of this product ion was very unstable. Compound 6 has been identified as alisol C by Q-TOF-MS with positive mode $^{8}$.

In comparison with TIC in positive mode previously reported $^{8}$, compound $\mathbf{2 0}$ (Fig. 1) is a major component in Ze $\mathrm{Xie}$ and has been identified as alisol A. This structural assignment was confirmed by the ion at $\mathrm{m} / z, 535.4588$ in negative MS (Fig. 5) in accord with the $\mathrm{C}_{31} \mathrm{H}_{51} \mathrm{O}_{7}$, a $[\mathrm{M}+\mathrm{HCOOH}-\mathrm{H}]^{-}$ of alisol A. HR-MS of compound 20 in positive mode exhibited a $[2 \mathrm{M}+\mathrm{H}]^{+}$of alisol $\mathrm{A}$ at $\mathrm{m} / \mathrm{z}, 981.6715$ corresponding to $\mathrm{C}_{60} \mathrm{H}_{101} \mathrm{O}_{10}$ (calculated for $\mathrm{C}_{60} \mathrm{H}_{101} \mathrm{O}_{10}, 981.7395$ ). A protonated molecular ion $[\mathrm{M}+\mathrm{H}]^{+}$at $\mathrm{m} / \mathrm{z} 491$ was detected, although the peak intensity was very weak. Product ions at $m / z 473,455$, 437 and 419 were generated by eliminating a series of $\mathrm{H}_{2} \mathrm{O}$ after depolymerization of $[2 \mathrm{M}+\mathrm{H}]^{+}$at $\mathrm{m} / z$ 981. As shown in Fig. 6, the MS/MS collision energy of $35 \mathrm{eV}$ was used to obtain extensive fragmentation information for this compound. The negative product ions from parent ion $[\mathrm{M}+\mathrm{HCOOH}-\mathrm{H}]^{-}$ at $m / z 535$ shown in Fig. 5 confirm this result. In negative mode with MS/MS collision energy of $15 \mathrm{eV}$, parent ion $[\mathrm{M}+\mathrm{HCOOH}-\mathrm{H}]^{-}$at $\mathrm{m} / \mathrm{z} 535$ generated two product ions 489 and 471. When MS/MS collision energy was $35 \mathrm{eV}$, compound 20 gave a ion at $m / z .1025 .8271$ corresponding to $\mathrm{C}_{61} \mathrm{H}_{101} \mathrm{O}_{12}$ $[2 \mathrm{M}+\mathrm{HCOOH}-\mathrm{H}]^{-}$(calculated for $\mathrm{C}_{61} \mathrm{H}_{101} \mathrm{O}_{12}, 1025.7293$ ). The $[2 \mathrm{M}+\mathrm{HCOOH}-\mathrm{H}]$ as a parent ion yielded product ions at $m / z, 535,489,471,435,413,395,377,353$ and 339 with a
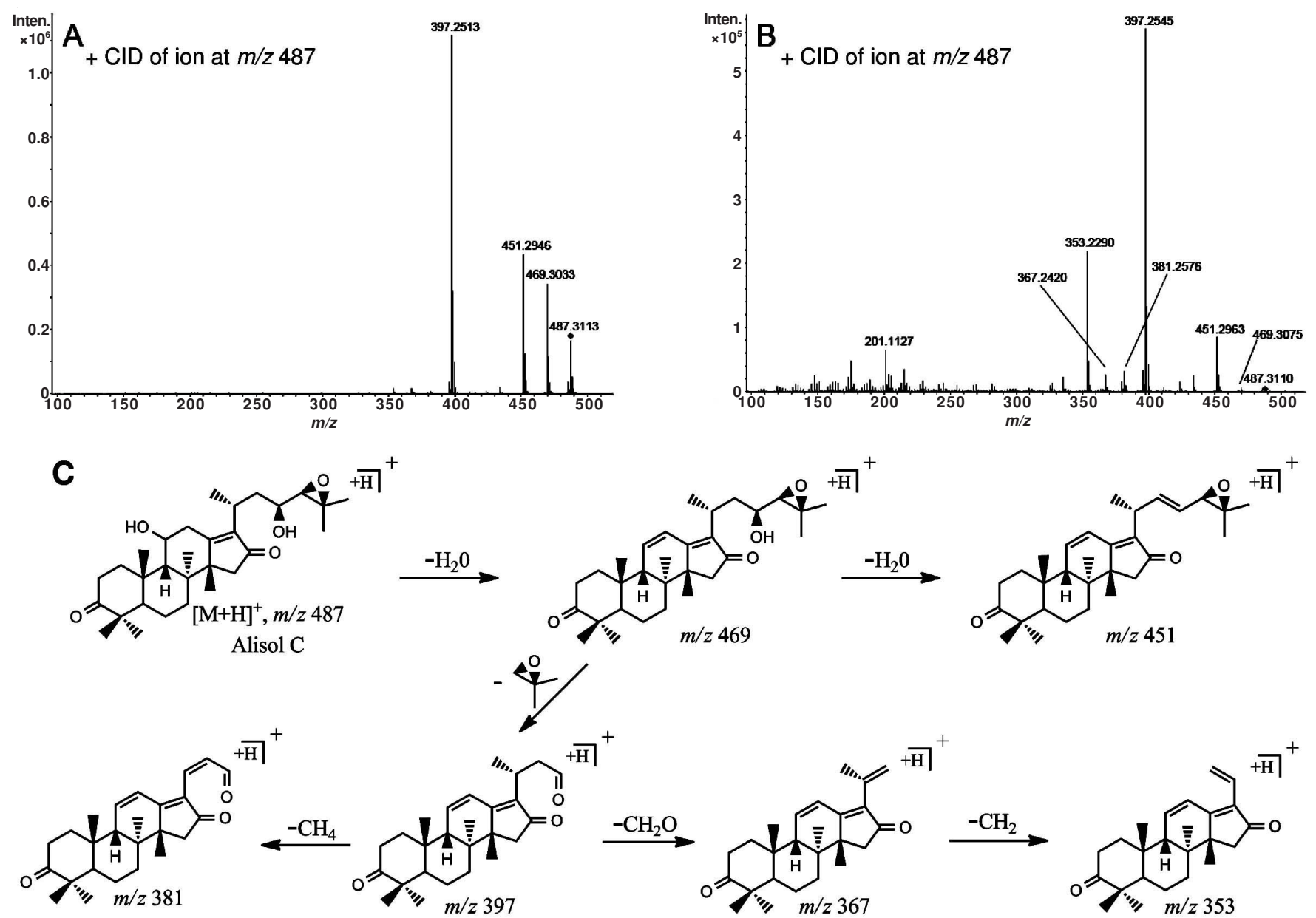

Fig. 3. CID MS/MS positive mass spectrum obtained from $[\mathrm{M}+\mathrm{H}]^{+}$of compound 6 at $\mathrm{m} / \mathrm{z}$ 487.3110: A, with MS/MS collision energy at 15 eV; B, with MS/ MS collision energy at $35 \mathrm{eV}$. C, proposed fragmentation pathway of compound $\mathbf{6}$ 

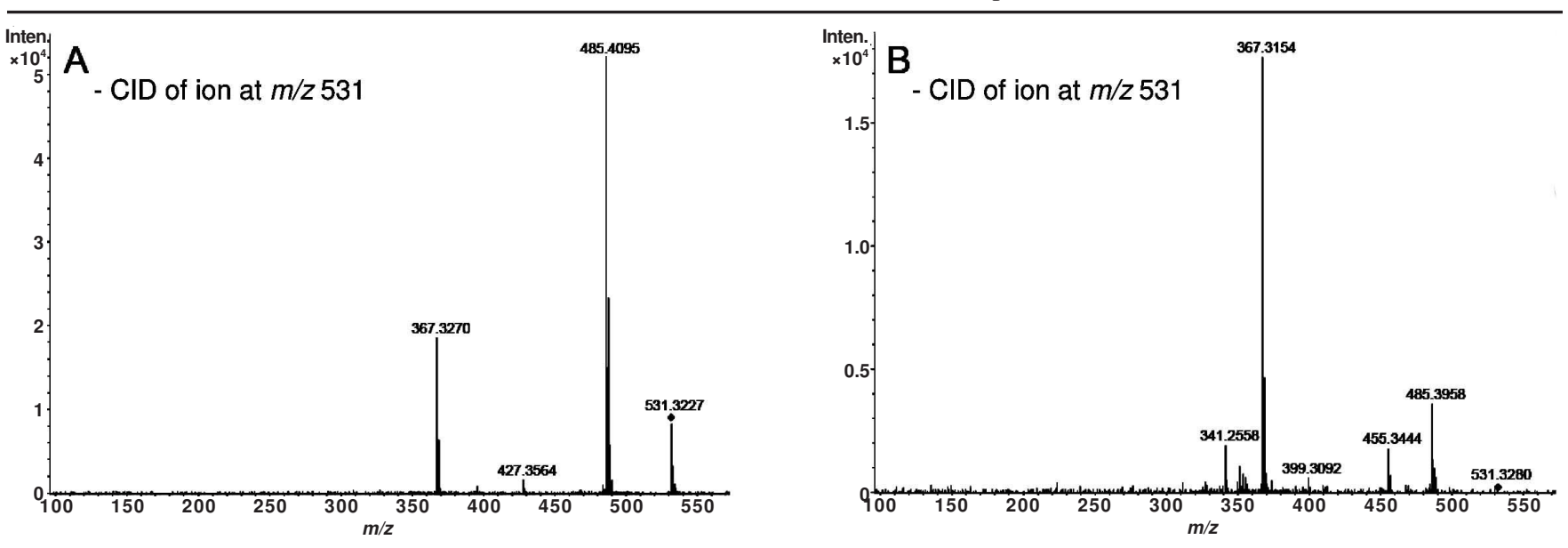

C
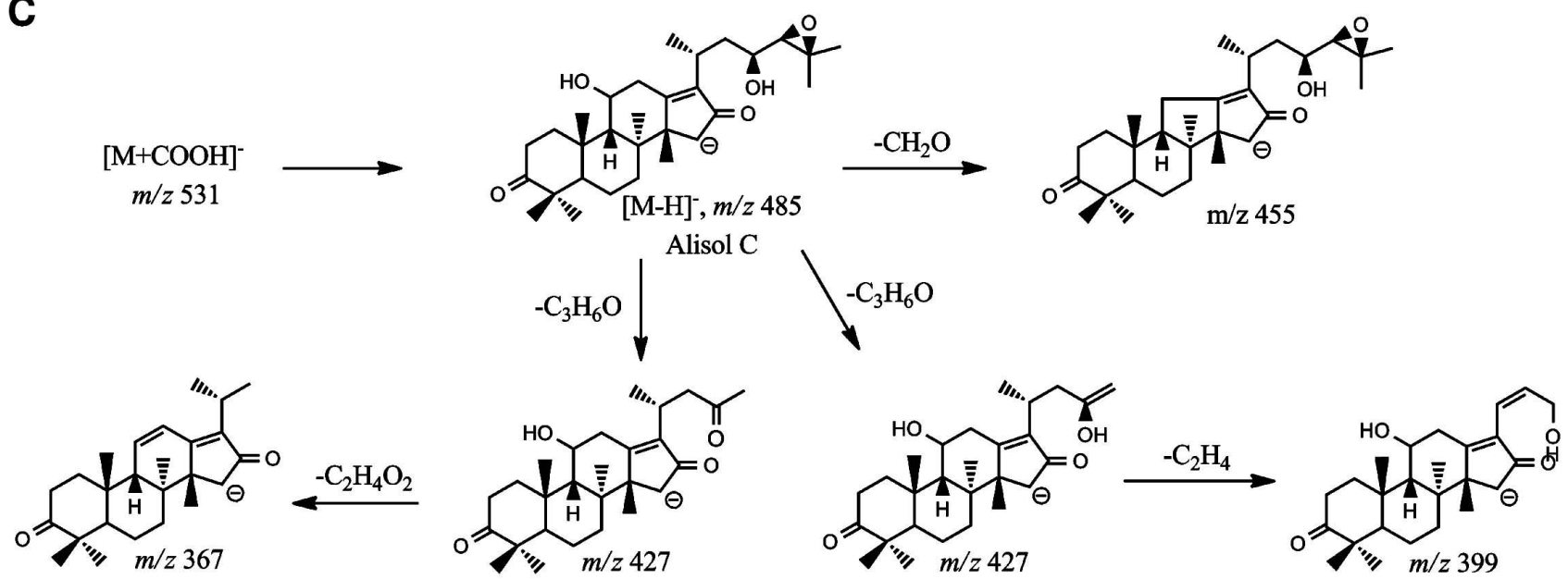

Fig. 4. CID MS/MS negative mass spectrum obtained from $[\mathrm{M}+\mathrm{HCOOH}-\mathrm{H}]^{-}$of compound $\mathbf{6}$ at $\mathrm{m} / z$. 531.3280: A, with MS/MS collision energy at 15 eV; B, with MS/MS collision energy at $35 \mathrm{eV}$. C, proposed fragmentation pathway of compound $\mathbf{6}$

MS/MS collision energy of $35 \mathrm{eV}$. The ion at $\mathrm{m} / \mathrm{z}, 535$ was alisol A-formic acid adduct $\left([\mathrm{M}+\mathrm{HCOOH}-\mathrm{H}]^{-}\right)$. The ions at $\mathrm{m} / \mathrm{z}, 471$ and 435 were generated by losing a series of $\mathrm{H}_{2} \mathrm{O}$ from the molecular ion [M-H] ${ }^{-}$at $m / z$ 489. The ion at $m / z, 413$ was generated by loss of $\mathrm{C}_{3} \mathrm{H}_{4}$ in the side chain from the ion at $\mathrm{m} / \mathrm{z} 453$ and followed by a series elimination of $\mathrm{H}_{2} \mathrm{O}$ to yield ions at $m / z 395$ and 377. All HR-MS and MS/MS data supported the assignment of alisol A to compound $\mathbf{2 0 .}$

Alisol A 23-acetate and alisol A 24-acetate as major components have been identified in $\mathrm{Ze} \mathrm{Xie}^{8}$. In positive mode, compounds 21 (HR-MS: $m / z$ 515.3374) and 24 (HR-MS: $m / z$ 515.3406) had the same ions in accordance with a $\mathrm{C}_{32} \mathrm{H}_{51} \mathrm{O}_{5}$, a formula of alisol A acetate $\left[\mathrm{M}+\mathrm{H}-\mathrm{H}_{2} \mathrm{O}\right]^{+}$(m.w. calculated for $\left.\mathrm{C}_{32} \mathrm{H}_{51} \mathrm{O}_{5}, 515.3736\right)$. HR-MS of these two compounds with negative mode exhibited almost identical $[\mathrm{M}+\mathrm{HCOOH}-\mathrm{H}]^{-}$ion at $\mathrm{m} / \mathrm{z}, 577.3496$ and 577.3190 corresponding to $\mathrm{C}_{33} \mathrm{H}_{53} \mathrm{O}_{8}$ $[\mathrm{M}+\mathrm{HCOOH}-\mathrm{H}]^{-}$(m.w. calculated for $\mathrm{C}_{33} \mathrm{H}_{53} \mathrm{O}_{8}, 577.3740$ ). Acetylation is a common biosynthetic pathway of protostane triterpenoid. Many protostane triterpenoids in Ze Xie have acetyl derivatives. For MS/MS of $\left[\mathrm{M}+\mathrm{H}-\mathrm{H}_{2} \mathrm{O}\right]^{+}$from compounds 21 and 24, the product ions at $m / z 455,437,419,383$, 365, 339 were identical to that of compound $\mathbf{2 0}$ (alisol A). The product ions at $\mathrm{m} / \mathrm{z}, 497$ and 479 were generated by elimination of one or two $\mathrm{H}_{2} \mathrm{O}$ from $\left[\mathrm{M}+\mathrm{H}_{-} \mathrm{H}_{2} \mathrm{O}\right]^{+}$at $\mathrm{m} / z, 515$ followed by loss of a acetyl group to yield ions at $m / z 455$ and 437. Based on the retention time on HPLC and different peak abundance in TIC mass spectrum, compound $\mathbf{2 1}$ and $\mathbf{2 4}$ were identified as alisol A 23-acetate and alisol A 24-acetate, as reported previously ${ }^{8}$. In negative mode with a high MS/MS collision energy of $35 \mathrm{eV}$, these two compounds exhibited ions at $\mathrm{m} / \mathrm{z}, 1109.8260$ and 1109.8035 , respectively and both were in accord with the $\mathrm{C}_{65} \mathrm{H}_{105} \mathrm{O}_{13}$ formula, a [2M+HCOOH-H] $]^{-}$of alisol A acetate (m.w. calculated for $\mathrm{C}_{65} \mathrm{H}_{105} \mathrm{O}_{13}, 1109.7504$ ). Unlike alisol A, only three product ions $[\mathrm{M}+\mathrm{HCOOH}-\mathrm{H}]^{-}$ at $m / z, 577,[\mathrm{M}-\mathrm{H}]^{-}$at $m / z, 531$ and $\left[\mathrm{M}-\mathrm{H} \text {-acetyl- } \mathrm{H}_{2} \mathrm{O}\right]^{-}$at $m / z$ 471 were observed from CID of [2M+HCOOH-H] $]^{-}$.

Alisol B has been reported to be a major component in Ze Xie ${ }^{8}$. HR-MS of compound 28 showed a ion at $\mathrm{m} / \mathrm{z}$ 945.9709 corresponding to $\mathrm{C}_{60} \mathrm{H}_{97} \mathrm{O}_{8}$ formula, a $[2 \mathrm{M}+\mathrm{H}]^{+}$of alisol B. The calculated value for $\mathrm{C}_{60} \mathrm{H}_{97} \mathrm{O}_{8}$ is 945.7183 . The ions at $\mathrm{m} / \mathrm{z} 455,437$ and 419 were generated by elimination of a series of $\mathrm{H}_{2} \mathrm{O}$ from the protonated molecular ion $[\mathrm{M}+\mathrm{H}]^{+}$ at $\mathrm{m} / \mathrm{z}$ 473. Like alisol C, a ion at $\mathrm{m} / \mathrm{z}, 383$ was formed by cleavage of $\mathrm{C}_{23}-\mathrm{C}_{24}$ bond via hydrogen rearrangement at $\mathrm{C}_{23}-\mathrm{OH}$, then followed by elimination of a $\mathrm{H}_{2} \mathrm{O}$ to yield a ion at $\mathrm{m} / \mathrm{z} 365$ (Fig. 7). Meanwhile, the ions at $\mathrm{m} / \mathrm{z} 353$ and 341 were generated by loss of $\mathrm{C}_{5} \mathrm{H}_{6}$ or $\mathrm{C}_{6} \mathrm{H}_{8} \mathrm{O}$ from the ion at $\mathrm{m} / z$ 419 and 437, respectively. In negative mode, this compound yielded base peak ion $[\mathrm{M}+\mathrm{HCOOH}-\mathrm{H}]^{-}$at $m / z 517$ and a product ion $\left[\mathrm{M}-\mathrm{H}_{2} \mathrm{O}\right]^{-}$at $m / z$ 453. All MS data supported the assignment of alisol B to compound $\mathbf{2 8}$. 

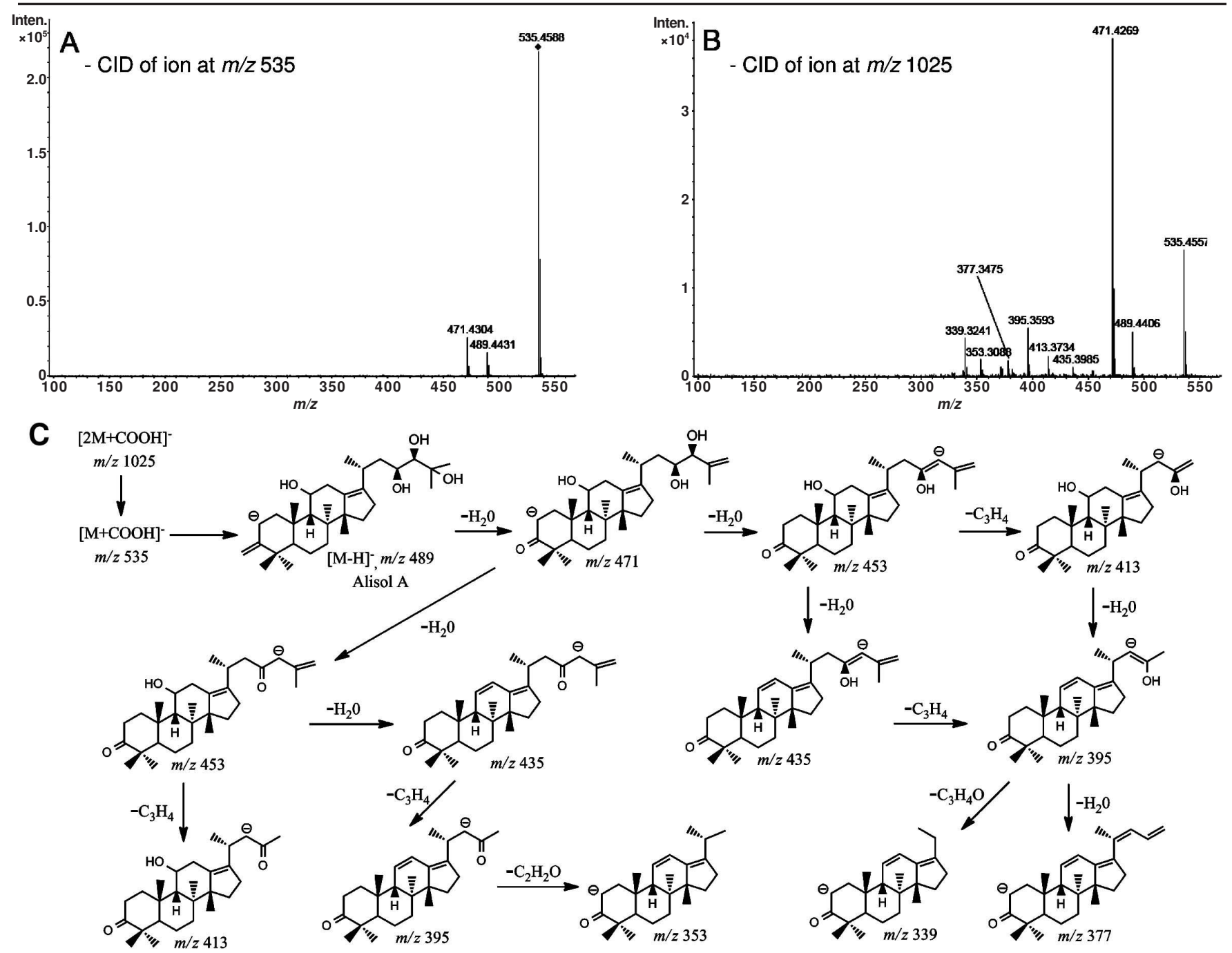

Fig. 5. CID MS/MS negative mass spectrum obtained from: A, $[\mathrm{M}+\mathrm{HCOOH}-\mathrm{H}]^{-}$of compound 20 at $\mathrm{m} / z$ 535.4588 with $\mathrm{MS} / \mathrm{MS}$ collision energy at 15 eV; $\mathbf{B},[2 \mathrm{M}+\mathrm{HCOOH}-\mathrm{H}]^{-}$of compound 20 at $\mathrm{m} / z 1025.8271$ with MS/MS collision energy at $35 \mathrm{eV}$. C, proposed fragmentation pathway of compound 20

Identification of minor protostane triterpenoids in Ze Xie: Compounds 1, 2, 7, 8, 13, 19 and 29 have been reported in $\mathrm{Ze} \mathrm{Xie}^{8}$, which were also identified in the present study using HR-molecular ion and its product ions. Compound 25 exhibited a ion at $m / z 471.3109$ corresponding to $\mathrm{C}_{32} \mathrm{H}_{50} \mathrm{O}_{6}$, a $[\mathrm{M}+\mathrm{H}]^{+}$of 11-deoxy-alisol C or 16, 23-oxido-alisol B, which have been reported in $\mathrm{Ze} \mathrm{Xie}^{8}$. In negative mode, an expected formic acid adduct $[\mathrm{M}+\mathrm{HCOOH}-\mathrm{H}]^{-}$was observed at $\mathrm{m} / z$ 515.3483. The $[\mathrm{M}+\mathrm{H}]^{+}$and $[\mathrm{M}+\mathrm{HCOOH}-\mathrm{H}]^{-}$suggested the molecular formula $\mathrm{C}_{32} \mathrm{H}_{50} \mathrm{O}_{6}$ for this compound. Together with the product ions at $m / z, 453,435,413,381$ and 363 from parent ion $[\mathrm{M}+\mathrm{H}]^{+}$at $m / z$ 471, compound 25 was characterized as 11-deoxy-alisol C or 16, 23-oxido-alisol B and final identification of compound $\mathbf{2 5}$ could not be completed by the LCMS/MS in this study.

Based on the MS and fragmentation patterns of components discussed above, almost identical MS and fragmentation patterns (Table-1) suggested that compound $\mathbf{4}$ was a isomer of compound 2; compound $\mathbf{1 1}$ was a isomer of compound $\mathbf{6}$; compounds 12, 14 and 15 were the isomers of compound 7; Compound $\mathbf{1 6}$ was a isomer of compound 20; Compound $\mathbf{1 7}$ was a isomer of compound $\mathbf{1}$; compounds $\mathbf{2 2}$ and $\mathbf{2 6}$ were the isomers of compound $\mathbf{2 1}$ and compound $\mathbf{2 3}$ was a isomer of $\mathbf{8}$. As neither NMR data of these minor compounds nor the corresponding standards were available, identification of $\mathbf{4}$, $11,12,14,15,16,17,22,23$ and 26 could not be completed by the LC-MS/MS in this study.

HR-MS in positive mode of compound $\mathbf{3}$ showed a ion at $m / z, 503.3004$ corresponding to $\mathrm{C}_{30} \mathrm{H}_{47} \mathrm{O}_{6}$ (m.w. calculated for $\mathrm{C}_{30} \mathrm{H}_{47} \mathrm{O}_{6}, 503.3372$ ). $\mathrm{C}_{30} \mathrm{H}_{47} \mathrm{O}_{6}$ formula accorded a [M$\left.\mathrm{H}_{2} \mathrm{O}+\mathrm{H}\right]^{+}$of dehydro-16-oxo-alisol A. In negative mode, compound 3 gave a ion at $\mathrm{m} / \mathrm{z} 547.3876$ corresponding to $\mathrm{C}_{31} \mathrm{H}_{47} \mathrm{O}_{8}$ (m.w. calculated for $\mathrm{C}_{31} \mathrm{H}_{47} \mathrm{O}_{8}, 547.3271$ ), which was in accord with $[\mathrm{M}+\mathrm{HCOOH}-\mathrm{H}]^{-}$of dehydro-16-oxo-alisol A. The fragmentation pattern of compound $\mathbf{3}$ was similar to that of 16-oxo-alisol A. In positive mode, the product ions at $\mathrm{m} / \mathrm{z}$ 485,467 and 413 were two hydrogens less than the ions at $\mathrm{m} / \mathrm{z}$ 487, 469 and 415 generated from 16-oxo-alisol A (compound 1) suggesting that compound $\mathbf{3}$ was an olefination derivative of compound 1. Although the exact position of this double bond could not be determined by MS data, the little difference of retention time and the same UV max. at $222 \mathrm{~nm}$ between compounds $\mathbf{1}$ and $\mathbf{3}$ indicated that the conjugated system of protostane triterpenoid skeleton of compound $\mathbf{3}$ was not changed 


\begin{tabular}{|c|c|c|c|c|c|c|}
\hline \multirow{3}{*}{ No. } & \multicolumn{6}{|c|}{$\begin{array}{c}\text { TABLE-1 } \\
\text { Q-TOF-MS DATA OF COMPOUNDS DETECTED IN AC }\end{array}$} \\
\hline & \multirow{2}{*}{$\begin{array}{c}\mathrm{Rt} \\
(\mathrm{min})\end{array}$} & \multirow{2}{*}{ Identification } & \multirow{2}{*}{ m.f. } & \multirow{2}{*}{$\begin{array}{l}\text { Ionization } \\
\text { mode }\end{array}$} & \multicolumn{2}{|c|}{ Product ions from CID, $\mathrm{m} / \mathrm{z}$ (relative intensity \%) } \\
\hline & & & & & Parent ion & Product ions \\
\hline \multirow[t]{2}{*}{1} & \multirow[t]{2}{*}{21.0} & \multirow[t]{2}{*}{ 16-oxo-alisol A } & \multirow[t]{2}{*}{$\mathrm{C}_{30} \mathrm{H}_{48} \mathrm{O}_{6}$} & Positive & $\begin{array}{c}{[\mathrm{M}+\mathrm{H}]^{+}} \\
505.3213(9.2)\end{array}$ & 487 (21.2), 469 (23.6), 451 (9.4), 415 (100), 397 (2.1) \\
\hline & & & & Negative & $\begin{array}{r}{[\mathrm{M}+\mathrm{HCOOH}-\mathrm{H}]^{-}} \\
549.3395(10.2)\end{array}$ & 485 (100), 503 (16.3), 427 (11.9), 369 (26.9) \\
\hline \multirow[t]{2}{*}{2} & \multirow[t]{2}{*}{22.7} & \multirow[t]{2}{*}{$\begin{array}{l}\text { 16-oxo-alisol A } \\
\text { 24-actetate }\end{array}$} & \multirow[t]{2}{*}{$\mathrm{C}_{32} \mathrm{H}_{50} \mathrm{O}_{7}$} & Positive & $\begin{array}{c}{\left[\mathrm{M}-\mathrm{H}_{2} \mathrm{O}+\mathrm{H}\right]^{+}} \\
529.3184(53.8)\end{array}$ & $\begin{array}{c}511(8.3), 497(2.4), 487(1.7), 469(60.8), 451(100), 415 \\
\text { (22.3), } 397 \text { (11.1), } 379(2.6), 353(2.7),\end{array}$ \\
\hline & & & & Negative & $\begin{array}{r}{[\mathrm{M}+\mathrm{HCOOH}-\mathrm{H}]^{-}} \\
591.3963(30.4)\end{array}$ & 545 (17.9), 527 (100), 485 (13.1), 467 (62.1), 367 (3.4) \\
\hline \multirow[t]{2}{*}{$3 *$} & \multirow[t]{2}{*}{23.9} & \multirow[t]{2}{*}{$\begin{array}{l}\text { dehydro-16- } \\
\text { oxo-alisol A }\end{array}$} & \multirow[t]{2}{*}{$\mathrm{C}_{30} \mathrm{H}_{46} \mathrm{O}_{6}$} & Positive & $\begin{array}{c}{[\mathrm{M}+\mathrm{H}]^{+}} \\
503.3004(9.3)\end{array}$ & $\begin{array}{c}485(51.2), 467(19.1), 445(32.4), 427(8.3), 413(100), \\
395(5.7), 353(1.8)\end{array}$ \\
\hline & & & & Negative & $\begin{array}{c}{[\mathrm{M}+\mathrm{HCOOH}-\mathrm{H}]^{-}} \\
547.3876(13.7)\end{array}$ & $\begin{array}{c}503(53.2), 501(21.3), 483(12.6), 443(15.5), 425(100), \\
407(11.8), 353(18.4), 327(21.0)\end{array}$ \\
\hline \multirow[t]{2}{*}{$4^{*}$} & \multirow[t]{2}{*}{26.1} & \multirow[t]{2}{*}{ Isomer of 2} & \multirow[t]{2}{*}{$\mathrm{C}_{32} \mathrm{H}_{50} \mathrm{O}_{7}$} & Positive & $\begin{array}{c}{[\mathrm{M}+\mathrm{H}]^{+}} \\
547.3876(1.6)\end{array}$ & $\begin{array}{c}529(100), 511(5.8), 469(28.4), 451(63.2), 433(4.0) \\
415(22.6), 397(1.1)\end{array}$ \\
\hline & & & & Negative & $\begin{array}{c}{[\mathrm{M}+\mathrm{HCOOH}-\mathrm{H}]^{-}} \\
591.3677(8.2)\end{array}$ & $545(28.0), 527(100), 485(12.0), 467$ (39.0), 367 (2.5) \\
\hline \multirow[t]{2}{*}{$5^{*}$} & \multirow[t]{2}{*}{28.2} & \multirow[t]{2}{*}{$\begin{array}{l}\text { dihydro-16-oxo- } \\
\text { alisol A }\end{array}$} & \multirow[t]{2}{*}{$\mathrm{C}_{30} \mathrm{H}_{50} \mathrm{O}_{6}$} & Positive & $\begin{array}{c}{[\mathrm{M}+\mathrm{Na}]^{+}} \\
529.3163(100)\end{array}$ & $511(2.0), 451(1.1)$ \\
\hline & & & & Negative & $\begin{array}{c}{[\mathrm{M}+\mathrm{HCOOH}-\mathrm{H}]^{-}} \\
551.3886(100)\end{array}$ & 505 (42.4), $487(1.7)$ \\
\hline \multirow[t]{2}{*}{6} & 31.8 & Alisol C & $\mathrm{C}_{30} \mathrm{H}_{46} \mathrm{O}_{5}$ & Positive & $\begin{array}{c}{[\mathrm{M}+\mathrm{H}]^{+}} \\
487.3110(0.03)\end{array}$ & $\begin{array}{c}469(1.0), 451(14.8), 433(4.3), 423(2.6), 397(100), 381 \\
(5.6), 367(4.5), 353(38.4)\end{array}$ \\
\hline & & & & Negative & $\begin{array}{c}{[\mathrm{M}+\mathrm{HCOOH}-\mathrm{H}]^{-}} \\
531.3280(0.48)\end{array}$ & $\begin{array}{c}485(20.2), 455(9.9), 399(3.2), 367(100), 351(6.1), 341 \\
(10.8)\end{array}$ \\
\hline 7 & 34.7 & $\begin{array}{l}\text { Alisol C 23- } \\
\text { acetate }\end{array}$ & $\mathrm{C}_{32} \mathrm{H}_{48} \mathrm{O}_{6}$ & Positive & $\begin{array}{c}{[\mathrm{M}+\mathrm{H}]^{+}} \\
529.3134(2.3)\end{array}$ & $\begin{array}{c}511(71.6), 493(6.9), 469(20.8), 451(100), 433(28.2) \text {, } \\
397(15.7)\end{array}$ \\
\hline & & & & Negative & $\begin{array}{c}{[\mathrm{M}+\mathrm{HCOOH}-\mathrm{H}]^{-}} \\
573.3621(19.7)\end{array}$ & 527 (100), 509 (25.4), 485 (14.1), 468 (17.1) \\
\hline 8 & 36.2 & $\begin{array}{l}\text { Alisol N 23- } \\
\text { acetate }\end{array}$ & $\mathrm{C}_{32} \mathrm{H}_{50} \mathrm{O}_{6}$ & Positive & $\begin{array}{c}{[\mathrm{M}+\mathrm{H}]^{+}} \\
531.3277(7.5)\end{array}$ & $\begin{array}{c}513(73.9), 495(11.2), 471(12.7), 453(100), 435(47.2), \\
417(5.6), 399(24.3), 381(42.7), 363(14.7), 355(10.2)\end{array}$ \\
\hline & & & & Negative & $\begin{array}{c}{[\mathrm{M}+\mathrm{HCOOH}-\mathrm{H}]^{-}} \\
575.3586(12.0)\end{array}$ & $529(100), 487(13.5), 469(19.9), 451(6.5)$ \\
\hline 9 & 37.2 & Unknown & & Positive & $\begin{array}{c}{[\mathrm{M}+\mathrm{H}]^{+}} \\
543.3247(100)\end{array}$ & $525(1.2), 495(2.2), 431(1.3), 413(2.8)$ \\
\hline & & & & Negative & $\begin{array}{c}{[\mathrm{M}+\mathrm{HCOOH}-\mathrm{H}]^{-}} \\
587.4219(100)\end{array}$ & $541(16.2), 519(34.2)$ \\
\hline $10^{*}$ & 38.1 & $\begin{array}{l}\text { Hydroxy-16- } \\
\text { oxo-alisol A 24- } \\
\text { actetate }\end{array}$ & $\mathrm{C}_{32} \mathrm{H}_{50} \mathrm{O}_{8}$ & Positive & $\begin{array}{c}{\left[\mathrm{M}-\mathrm{H}_{2} \mathrm{O}+\mathrm{H}\right]^{+}} \\
545.3097(100) \\
{[\mathrm{M}-\mathrm{H}]^{-}}\end{array}$ & $\begin{array}{c}527(27.5), 509(11.3), 485(59.9), 467(97.7), 449(37.4), \\
431(48.8), 413(58.1), 387(69.0), 369(16.6) \\
517(19.1), 501(30.9)\end{array}$ \\
\hline & & & & Negative & $561.3960(100)$ & \\
\hline $11^{*}$ & 39.1 & Isomer of 6 & $\mathrm{C}_{30} \mathrm{H}_{46} \mathrm{O}_{5}$ & Positive & $\begin{array}{c}{[\mathrm{M}+\mathrm{H}]^{+}} \\
487.3419(33.6)\end{array}$ & $\begin{array}{c}469(97.4), 451(13.5), 427(5.1), 397(100), 381(10.5) \text {, } \\
355(14.5)\end{array}$ \\
\hline & & & & Negative & $\begin{array}{c}{[\mathrm{M}+\mathrm{HCOOH}-\mathrm{H}]^{-}} \\
531.3570(41.1)\end{array}$ & 485 (100), 427 (21.9), 353 (12.3), 327 (14.5) \\
\hline $12 *$ & 40.3 & Isomer of 7 & $\mathrm{C}_{32} \mathrm{H}_{48} \mathrm{O}_{6}$ & Positive & $\begin{array}{c}{\left[\mathrm{M}-\mathrm{H}_{2} \mathrm{O}+\mathrm{H}\right]^{+}} \\
511.3088(100)\end{array}$ & 493 (2.7), 451 (45.6), 433 (78.4), 397 (10.5), 353 (2.8) \\
\hline & & & & Negative & $\begin{array}{c}{[\mathrm{M}+\mathrm{HCOOH}-\mathrm{H}]^{-}} \\
573.3566(14.3)\end{array}$ & 527 (100), 467 (14.6) \\
\hline 13 & 40.8 & Alisol F & $\mathrm{C}_{30} \mathrm{H}_{48} \mathrm{O}_{5}$ & Positive & $\begin{array}{c}{\left[\mathrm{M}-\mathrm{H}_{2} \mathrm{O}+\mathrm{H}\right]^{+}} \\
471.3115(1.8)\end{array}$ & $\begin{aligned} & 453(3.6), 395(2.9), 381(14.2), 363(3.7), 339(100), 321 \\
&(5.2), 297(11.1)\end{aligned}$ \\
\hline & & & & Negative & $\begin{array}{c}{[\mathrm{M}+\mathrm{HCOOH}-\mathrm{H}]^{-}} \\
533.3478(100)\end{array}$ & 487 (34.2), 449 (15.6), $409(16.8)$ \\
\hline $14^{*}$ & 42.7 & Isomer of 7 & $\mathrm{C}_{32} \mathrm{H}_{48} \mathrm{O}_{6}$ & Positive & $\begin{array}{c}{[\mathrm{M}+\mathrm{H}]^{+}} \\
529.3166(100)\end{array}$ & $511(10.1), 469$ (31.2), 451 (57.8), $433(5.7), 415$ (15.9) \\
\hline & & & & Negative & $\begin{array}{c}{[\mathrm{M}+\mathrm{HCOOH}-\mathrm{H}]^{-}} \\
573.3899(3.1)\end{array}$ & $527(2.7), 509(100), 467(4.2), 449(3.3)$ \\
\hline $15^{*}$ & 44.6 & Isomer of 7 & $\mathrm{C}_{32} \mathrm{H}_{48} \mathrm{O}_{6}$ & Positive & $\begin{array}{c}{[\mathrm{M}+\mathrm{H}]^{+}} \\
529.3134(17.3)\end{array}$ & $\begin{array}{c}511(100), 493(7.2), 469(10.2), 451(17.4), 433(8.1), \\
397(11.9), 353(2.6)\end{array}$ \\
\hline & & & & Negative & $\begin{array}{c}{[\mathrm{M}+\mathrm{HCOOH}-\mathrm{H}]^{-}} \\
573.3139(29.5)\end{array}$ & 527 (100), 503 (12.7), 485 (23.2), 467 (78.8) \\
\hline $16^{*}$ & 45.1 & Isomer of 20 & $\mathrm{C}_{30} \mathrm{H}_{50} \mathrm{O}_{5}$ & Positive & $\begin{array}{c}{[\mathrm{M}+\mathrm{Na}]^{+}} \\
513.3455(100)\end{array}$ & 495 (3.2), 455 (1.8), $437(6.3), 383(2.2)$ \\
\hline & & & & Negative & $\begin{array}{c}{[\mathrm{M}+\mathrm{HCOOH}-\mathrm{H}]^{-}} \\
535.2821(100)\end{array}$ & $489(83.4)$ \\
\hline
\end{tabular}




\begin{tabular}{|c|c|c|c|c|c|c|}
\hline $17 *$ & 46.4 & Isomer of 1 & $\mathrm{C}_{30} \mathrm{H}_{48} \mathrm{O}_{6}$ & Negative & $\begin{array}{c}{\left[\mathrm{M}-\mathrm{H}_{2} \mathrm{O}+\mathrm{H}\right]^{+}} \\
487.3075(100) \\
{\left[\mathrm{M}+\mathrm{HCOOH}-\mathrm{H}^{-}\right.} \\
549.4380(100)\end{array}$ & 469 (35.9), 451 (56.4), 413 (14.2), 397 (49.7), 379 (17.5) \\
\hline $18^{*}$ & 47.5 & Isomer of 10 & $\mathrm{C}_{32} \mathrm{H}_{50} \mathrm{O}_{8}$ & $\begin{array}{l}\text { Positive } \\
\text { Negative }\end{array}$ & $\begin{array}{c}{\left[\mathrm{M}-\mathrm{H}_{2} \mathrm{O}+\mathrm{H}\right]^{+}} \\
545.3069(84.1) \\
{[\mathrm{M}-\mathrm{H}]^{-}} \\
561.3654(100)\end{array}$ & $\begin{array}{c}485(9.2), 467(22.3), 449(7.2), 431(39.5), 413(100), \\
387(65.2), 369(13.8), 353(8.8), 341(7.4) \\
501(27.6), 475(1.4)\end{array}$ \\
\hline 19 & 49.5 & Alisol O & $\mathrm{C}_{32} \mathrm{H}_{48} \mathrm{O}_{5}$ & Positive & $\begin{array}{c}{[\mathrm{M}+\mathrm{H}]^{+}} \\
513.3183(6.5)\end{array}$ & $\begin{array}{c}495(11.6), 455(3.0), 435(10.2), 417(3.4), 381(30.9) \\
363(7.0), 339(100)\end{array}$ \\
\hline 20 & 52.3 & Alisol A & $\mathrm{C}_{30} \mathrm{H}_{50} \mathrm{O}_{5}$ & $\begin{array}{l}\text { Positive } \\
\text { Negative }\end{array}$ & $\begin{array}{c}{[2 \mathrm{M}+\mathrm{H}]^{+}} \\
981.6715(0.9) \\
{[2 \mathrm{M}+\mathrm{HCOOH}-\mathrm{H}]^{-}} \\
1025.8271(0.2)\end{array}$ & $\begin{array}{l}491(0.8), 473(1.6), 455(8.3), 437(11.4), 419(4.9), 383 \\
(69.2), 365(100), 339(46.8) \\
535(37.4), 489(13.2), 471(100), 435(2.4), 413(5.8), \\
395(14.4), 377(4.6), 353(5.0), 339(11.3)\end{array}$ \\
\hline 21 & 54.8 & $\begin{array}{l}\text { Alisol A 23- } \\
\text { acetate }\end{array}$ & $\mathrm{C}_{32} \mathrm{H}_{52} \mathrm{O}_{6}$ & $\begin{array}{l}\text { Positive } \\
\text { Negative }\end{array}$ & $\begin{array}{c}{\left[\mathrm{M}-\mathrm{H}_{2} \mathrm{O}+\mathrm{H}\right]^{+}} \\
515.3374(67.8) \\
{[2 \mathrm{M}+\mathrm{HCOOH}-\mathrm{H}]^{-}} \\
1109.8260(5.3)\end{array}$ & $\begin{array}{c}497(52.7), 479(11.7), 455(19.8), 437(100), 419(65.3), \\
383(28.2), 365(44.0), 339(40.8) \\
577(100), 531(23.4)\end{array}$ \\
\hline $22 *$ & 55.6 & Isomer of 21 & $\mathrm{C}_{32} \mathrm{H}_{52} \mathrm{O}_{6}$ & $\begin{array}{l}\text { Positive } \\
\text { Negative }\end{array}$ & $\begin{array}{c}{\left[\mathrm{M}-\mathrm{H}_{2} \mathrm{O}+\mathrm{H}\right]^{+}} \\
515.3561(20.6) \\
{[\mathrm{M}+\mathrm{HCOOH}-\mathrm{H}]^{-}} \\
577.3954(100)\end{array}$ & $\begin{array}{c}497(76.6), 479(19.8), 455(14.2), 437(100), 419(21.3), \\
383(66.0), 365(57.1), 339(48.2) \\
531(9.2), 469(5.1)\end{array}$ \\
\hline $23^{*}$ & 56.9 & Isomer of 8 & $\mathrm{C}_{32} \mathrm{H}_{50} \mathrm{O}_{6}$ & $\begin{array}{l}\text { Positive } \\
\text { Negative }\end{array}$ & $\begin{array}{c}{\left[\mathrm{M}-\mathrm{H}_{2} \mathrm{O}+\mathrm{H}\right]^{+}} \\
513.3424(90.8) \\
{[\mathrm{M}+\mathrm{HCOOH}-\mathrm{H}]^{-}} \\
575.3679(100)\end{array}$ & $\begin{array}{c}495(14.9), 451(53.4), 435(20.1), 417(11.7), 399(5.3), \\
381(75.3), 363(33.1), 339(100) \\
529(9.4)\end{array}$ \\
\hline 24 & 67.0 & $\begin{array}{l}\text { Alisol A 24- } \\
\text { acetate }\end{array}$ & $\mathrm{C}_{32} \mathrm{H}_{52} \mathrm{O}_{6}$ & $\begin{array}{l}\text { Positive } \\
\text { Negative }\end{array}$ & $\begin{array}{c}{\left[\mathrm{M}-\mathrm{H}_{2} \mathrm{O}+\mathrm{H}\right]^{+}} \\
515.3406(100) \\
{[2 \mathrm{M}+\mathrm{HCOOH}-\mathrm{H}]^{-}} \\
1109.8035(0.8)\end{array}$ & $\begin{array}{c}497(7.5), 455(2.4), 437(20.8), 419(13.1), 383(44.5) \\
365(45.0), 339(38.3) \\
577(100), 531(27.9), 471(7.4)\end{array}$ \\
\hline 25 & 70.2 & $\begin{array}{l}\text { 11-deoxy-alisol } \\
\text { C or } 16,23- \\
\text { oxido-alisol B }\end{array}$ & $\mathrm{C}_{30} \mathrm{H}_{46} \mathrm{O}_{4}$ & $\begin{array}{l}\text { Positive } \\
\text { Negative }\end{array}$ & $\begin{array}{c}{[\mathrm{M}+\mathrm{H}]^{+}} \\
471.3109(18.8) \\
{[\mathrm{M}+\mathrm{HCOOH}-\mathrm{H}]^{-}} \\
515.3483(50.7)\end{array}$ & $\begin{array}{c}453(26.8), 435(23.1), 413(12.9), 381(78.6), 363(22.8), \\
339(100) \\
469(100)\end{array}$ \\
\hline $27 *$ & 73.4 & $\begin{array}{l}\text { Olefination } \\
\text { adduct of } 7\end{array}$ & $\mathrm{C}_{32} \mathrm{H}_{46} \mathrm{O}_{6}$ & Positive & $\begin{array}{c}{[\mathrm{M}+\mathrm{H}]^{+}} \\
527.3314(11.2)\end{array}$ & 509 (3.8), 469 (84.5), 451 (96.7), 433 (14.2), 397 (100) \\
\hline 28 & 75.0 & Alisol B & $\mathrm{C}_{30} \mathrm{H}_{48} \mathrm{O}_{4}$ & $\begin{array}{l}\text { Positive } \\
\text { Negative }\end{array}$ & $\begin{array}{c}{[2 \mathrm{M}+\mathrm{H}]^{+}} \\
945.5709(2.6) \\
{[\mathrm{M}+\mathrm{HCOOH}-\mathrm{H}]^{-}} \\
517.4447(100)\end{array}$ & $\begin{array}{c}473(17.6), 455(100), 437(81.9), 419(21.8), 383(20.3), \\
365(4.5), 341(21.5) \\
453(2.8)\end{array}$ \\
\hline 29 & 77.7 & $\begin{array}{l}\text { Alisol L or its } \\
\text { isomer }\end{array}$ & $\mathrm{C}_{30} \mathrm{H}_{44} \mathrm{O}_{4}$ & Positive & $\begin{array}{c}{[\mathrm{M}+\mathrm{H}]^{+}} \\
469.3019(100)\end{array}$ & $\begin{array}{c}451(23.8), 433(2.4), 411(4.0), 397(4.3), 381(4.7), 339 \\
(14.4)\end{array}$ \\
\hline
\end{tabular}

and suggested that the position of this double bond was situated in side chain.

HR-MS in negative mode of compound 5 showed a base peak at $m / z, 551.3886$ corresponding to $\mathrm{C}_{31} \mathrm{H}_{51} \mathrm{O}_{8}$, (m.w. calculated for $\mathrm{C}_{31} \mathrm{H}_{51} \mathrm{O}_{8}, 551.3584$ ), which was two more hydrogens than compound 1 (16-oxo-alisol A). In positive mode MS, a prominent ion at $\mathrm{m} / z 529.3163$ corresponding to $\mathrm{C}_{30} \mathrm{H}_{50} \mathrm{O}_{6} \mathrm{Na}$ (calculated for $\mathrm{C}_{30} \mathrm{H}_{50} \mathrm{O}_{6} \mathrm{Na}, 529.3505$ ) was detected. $\mathrm{C}_{31} \mathrm{H}_{51} \mathrm{O}_{8}$ and $\mathrm{C}_{30} \mathrm{H}_{50} \mathrm{O}_{6} \mathrm{Na}$ should be assigned to [M+ HCOOH$\mathrm{H}]^{-}$and $[\mathrm{M}+\mathrm{Na}]^{+}$of dihydro-16-oxo-alisol A. The product ions at $m / z, 505$ and 487 of $[\mathrm{M}+\mathrm{HCOOH}-\mathrm{H}]^{-}$at $\mathrm{m} / z, 551$ were $[\mathrm{M}-\mathrm{H}]^{-}$and $\left[\mathrm{M}-\mathrm{H}_{2} \mathrm{O}-\mathrm{H}\right]^{-}$, respectively. Thus, compound 5 was characterized as a di-hydrogenated derivative of compound $\mathbf{1}$. $\mathrm{CID}$ of $[\mathrm{M}+\mathrm{HCOOH}-\mathrm{H}]^{-}$and $[\mathrm{M}+\mathrm{Na}]^{+}$of this compound did not reveal any other characteristic fragments in neither high $(35 \mathrm{eV})$ nor low $(15 \mathrm{eV}) \mathrm{MS} / \mathrm{MS}$ collision energy and position of di-hydrogenation could not be determined.
HR-MS in positive mode of compounds $\mathbf{1 0}$ and $\mathbf{1 8}$ yielded base peaks at $m / z, 545.3097$ and $m / z, 545.3069$, respectively, were in accordance with a $\mathrm{C}_{32} \mathrm{H}_{49} \mathrm{O}_{7}$ formula (m.w. calculated for $\mathrm{C}_{32} \mathrm{H}_{49} \mathrm{O}_{7}, 545.3478$ ). In negative mode HR-MS, these two compounds gave base peaks at $\mathrm{m} / z 561.3960$ and 561.3654 corresponding to $\mathrm{C}_{32} \mathrm{H}_{49} \mathrm{O}_{8}$ formula (m.w. calculated for $\mathrm{C}_{32} \mathrm{H}_{49} \mathrm{O}_{8}, 561.3427$ ). Based on the MS behaviours in positive and negative modes of protostane triterpenoids in Ze Xie, $\mathrm{C}_{32} \mathrm{H}_{49} \mathrm{O}_{7}$ formula in positive mode and $\mathrm{C}_{32} \mathrm{H}_{49} \mathrm{O}_{8}$ formula in negative mode were assigned as $\left[\mathrm{M}+\mathrm{H}-\mathrm{H}_{2} \mathrm{O}\right]^{+}$and $[\mathrm{M}-\mathrm{H}]^{-}$of compounds 10 and 18. The same MS data suggested that compounds 10 and 18 were isomers. The $\left[\mathrm{M}+\mathrm{H}-\mathrm{H}_{2} \mathrm{O}\right]^{+}$at $m / z, 545$ and its product ions at $\mathrm{m} / \mathrm{z}, 527,485,467,431,413$ and 369 were exactly one oxygen more than that of compound 2 (16oxo-alisol A 24-actetate), [M $\left.+\mathrm{H}-\mathrm{H}_{2} \mathrm{O}\right]^{+}$at $\mathrm{m} / z, 529$ as well as its product ions at $m / z 511,469,451,415,397$ and 353. The MS data comparison suggested that one hydrogen of compound 


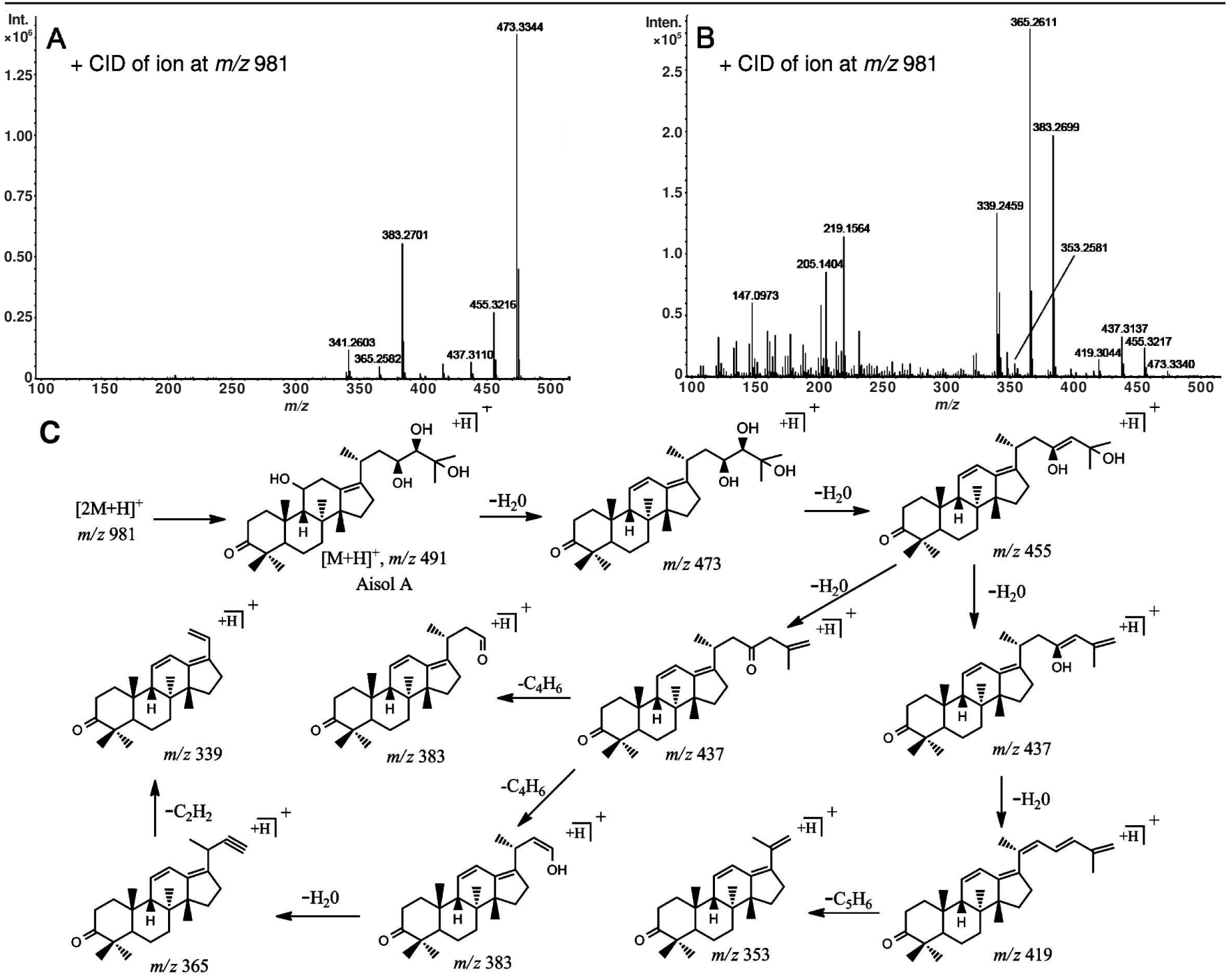

Fig. 6. CID MS/MS positive mass spectrum obtained from $[2 \mathrm{M}+\mathrm{H}]^{+}$of compound 20 at $m / z$ 981.6715: A, with MS/MS collision energy at 15 eV; $\mathbf{B}$, with MS/MS collision energy at $35 \mathrm{eV}$. C, proposed fragmentation pathway of compound $\mathbf{2 0}$

2 was replaced by a hydroxyl in compounds $\mathbf{1 0}$ and $\mathbf{1 8}$. However, the precise position of this hydroxyl was difficult to be certain of since NMR data or the corresponding standards of these two compounds were not available. Therefore, compound 10 and 18 were characterized as hydroxylated derivatives of compound 2.

HR-MS of compound 27 showed a prominent ion at $\mathrm{m} / \mathrm{z}$ 527.3314 corresponding to $\mathrm{C}_{32} \mathrm{H}_{47} \mathrm{O}_{6}$ (m.w. calculated for $\mathrm{C}_{32} \mathrm{H}_{47} \mathrm{O}_{6}, 527.3372$ ), which has two hydrogens less than that of compound 7. Based on the MS behaviours in positive mode of protostane triterpenoids in $\mathrm{Ze} \mathrm{Xie}, \mathrm{C}_{32} \mathrm{H}_{47} \mathrm{O}_{6}$ formula in positive mode was assigned as $[\mathrm{M}+\mathrm{H}]^{+}$of compound 27 . Its product ions at $\mathrm{m} / \mathrm{z} 469,433$ and 397 were identical to that of produced by compound 7 (Alisol C 23-acetate), suggesting that these two compound possessed a same protostane triterpenoid skeleton. Therefore, compound 27 was characterized as olefination derivative of compound $\mathbf{7}$ and had an additional double bond in side chain.

\section{Conclusion}

Using HPLC-DAD/HR-ESI-TOF-MS in this study, a reliable and sensitive method has been established for the analysis of protostane triterpenoids in Ze Xie. As a result, a total of 28 protostane triterpenoids were separated and simultaneously detected in Q-TOF-MS and 15 of them were newly found in Ze Xie. Our results showed that most protostane triterpenoids in $\mathrm{Ze}$ Xie generated diverse parent ions including $[\mathrm{M}+\mathrm{H}]^{+}$, $\left[\mathrm{M}-\mathrm{H}_{2} \mathrm{O}+\mathrm{H}\right]^{+}$and/or $[2 \mathrm{M}+\mathrm{H}]^{+}$in positive mode, which led to a rather difficult identification for their molecular ion. In negative mode, these protostane triterpenoids gave the most prominent ions of formic acid adduct $[\mathrm{M}+\mathrm{HCOOH}-\mathrm{H}]^{-}$in their mass spectra. Since authentic standards of many components in Ze Xie are un-available, more reliable analysis of protostane triterpenoids in crude extract of Ze Xie should be performed by comparing both positive and negative to determine the parent ions and their diagnostic CID fragments. This study demonstrated a reliable and sensitive method suitable for the analysis of protostane triterpenoids in Ze Xie and other herbs. Further work is clearly needed to separate pure compounds and identify the new bioactive protostane triterpenoids in Ze Xie by bioassays for determinations of their bioactivities and NMR and other methods for their final structural identification.

\section{ACKNOWLEDGEMENTS}

This work was supported by a grant (No. 30873469) from National Science Foundation of China. 

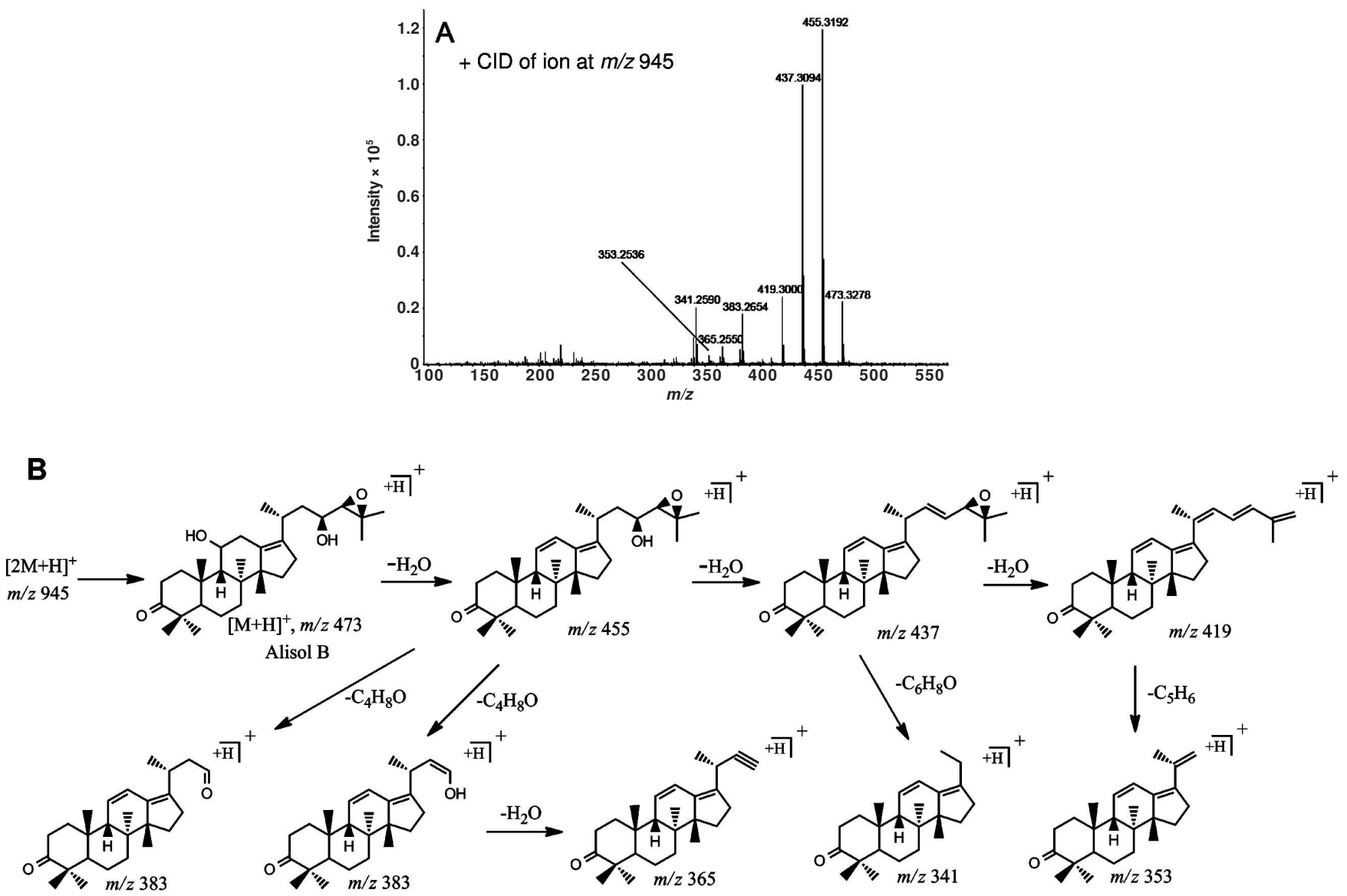

Fig. 7. CID MS/MS negative mass spectrum obtained from $[2 \mathrm{M}+\mathrm{H}]^{+}$of compound $\mathbf{2 8}$ at $\mathrm{m} / z$. 945.5709 with MS/MS collision energy at 15 eV (A) and its proposed fragmentation pathway $(\mathbf{B})$

\section{REFERENCES}

1. H. Dan, J. Wu, M. Peng, X. Hu, C. Song, Z. Zhou, S. Yu and N. Fang, Saudi Med. J., 32, 701 (2011).

2. G.P. Peng, G. Tian, X.F. Huang and F.C. Lou, Phytochemistry, 63, 877 (2003).

3. H. Matsuda, T. Kageura, I. Toguchida, T. Murakami, A. Kishi and M. Yoshikawa, Bioorg. Med. Chem. Lett., 9, 3081 (1999).

4. H. Matsuda, N. Tomohiro, M. Yoshikawa and M. Kubo, Biol. Pharm. Bull., 21, 1317 (1998).

5. M. Yoshikawa, S. Yamaguchi, H. Matsuda, N. Tanaka, J. Yamahara and N. Murakami, Chem. Pharm. Bull. (Tokyo), 42, 2430 (1994).
6. M. Yoshikawa, S. Yamaguchi, H. Matsuda, Y. Kohda, H. Ishikawa, N. Tanaka, J. Yamahara and N. Murakami, Chem. Pharm. Bull. (Tokyo), 42, 1813 (1994).

7. M. Yoshikawa, S. Yamaguchi, N. Chatani, Y. Nishino, T. Matsuoka, J. Yamahara, N. Murakami, H. Matsuda and M. Kubo, Yakugaku Zasshi, 114, 241 (1994).

8. X. Liu, S.L. Li, Y. Zhou, J.Z. Song, Y.F. Zheng, G.P. Peng and H.X. Xu, Rapid Commun. Mass Spectrom., 24, 1514 (2010).

9. X.Y. Guo, J. Han, M. Ye, X.C. Ma, X. Shen, B.B. Xue and Q.M. Che, J. Pharm. Biomed. Anal., 63, 29 (2012). 